TAPROBANICA, ISSN 1800-427X. December, 2013. Vol. 05, No. 02: pp. 102-110.

(C) Taprobanica Private Limited, 146, Kendalanda, Homagama, Sri Lanka.

http://www.sljol.info/index.php/tapro

\title{
ENVIRONMENTAL EFFECTS ON THE MORPHOLOGY OF THE SNOW TROUT Schizothorax richardsonii (GRAY, 1832)
}

\footnotetext{
${ }^{1}$ Wildlife Institute of India, P.O. Box No. 18, Chandrabani, Dehradun 248001, Uttarakhand, India

${ }^{2}$ Forest Research Institute, P.O. New Forest, Dehradun 248 001, Uttarakhand, India

E-mail: ${ }^{3}$ jaj@wii.gov.in
}

\begin{abstract}
This study examines the relationship between morphological traits related to body size and fin morphology and the environment in snow trout, Schizothorax richardsonii, a widespread species from the upper Ganga river basin, India. Three body shape traits (index of compression, index of trunk shape and relative body depth) and three fin traits (dorsal fin relative area, pectoral fin relative area and pectoral fin aspect ratio) were related to five environmental variables (water temperature, water flow, depth, conductivity and substrate diversity) across eight study streams. Water temperature, conductivity and substrate diversity were highly variable across the sampled sites. There was a significant negative correlation $(r=-0.676)$ between composite morphological traits (principal components) related to body size and fin morphology. Furthermore, both body size and fin morphology were strongly correlated $(\mathrm{r}=0.861$ and $\mathrm{r}=-0.845$ respectively) with composite environmental variables (water temperature, conductivity and substrate diversity) across sites. These findings suggest that the morphological traits of fish populations residing across environmental gradients are adapted to different habitats.
\end{abstract}

Key words: Schizothorax richardsonii, ecomorphology, environmental variables, Ganga River.

\section{Introduction}

Fishes inhabiting small and stable streams are often habitat specialists that have evolved various morphological and behavioral adaptations to exploit these specific habitat types (Gorman \& Karr, 1978; Wood \& Bain, 1995). Stream ecosystems are generally characterized by various geomorphological conditions such as channel slope and bed morphology that can profoundly influence the characteristics of resident fishes (Hubbs, 1941). In addition to these geomorphological conditions, environmental parameters such as water velocity, depth, substrate diversity and water temperature also influence the structural 
and functional morphology of fishes (Mahon, 1984). Such environmentally driven morphological changes in an organism are called ecomorphological traits, and understanding the influence an organism's ecology on its phenotype is known as ecomorphology (Ricklefs \& Cox, 1977). Understanding the morphological adaptations of fishes inhabiting broad environmental gradients can be a useful method for unravelling complex interactions between the environment and morphology. This approach also provides a better understanding of a species' habitat preferences and potential conservation significance.

Streams originating from the Himalayas are unique by virtue of their high altitude, fastflowing waters, heterogeneous substrate and low water temperatures due to snow melt and/or glacier fed water. A number of studies suggest that many morphological traits in fishes are influenced by the physico-chemical environment where they live (e.g. Balon et al., 1986; Bourke et al., 1997; Chan, 2001; Gatz, 1979; Langerhans et al., 2003; Mahon, 1984;
Motta et al., 1995; Watson \& Balon, 1984; Wikramanayake, 1990; Wood \& Bain, 1995). Body shape and fin size, in particular, are two important morphological characters that vary greatly in lentic vs. lotic habitats. Fishes living in swift flowing habitats generally have a cylindrical body with a small surface area to body volume ratio and stiff, short fins, while fishes in lentic habitat generally have a deep, laterally compressed body with large fins. (Aleev, 1969; Douglas \& Matthews, 1992; Gatz, 1979). Very little research has been conducted on stream fishes in India, and studies exploring intraspecific variation in fish morphology in relation to environmental variables have never been explored in Himalayan waters. Thus, the present study aims to examine the ecomorphological traits of snow trout, Schizothorax richardsonii, a common stream fish in the Himalayas across diverse environmental gradients. To achieve this goal, we quantified a set of environmental variables (water temperature, depth, flow, substrate diversity and conductivity) to determine whether these variables influence body and fin morphology in snow trout.

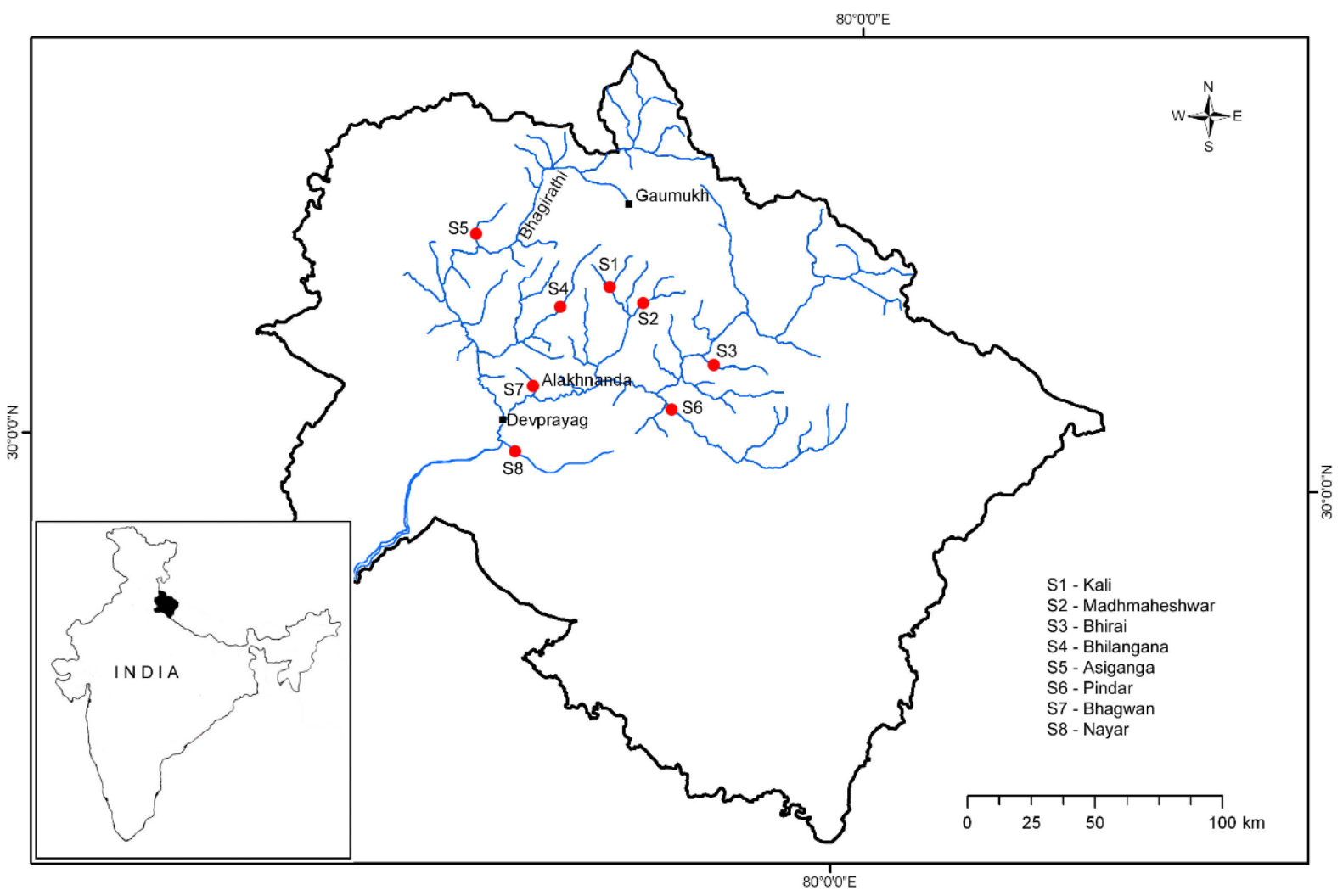

Figure 1: Location of the eight study sites in the upper Ganga River basin, India. 


\section{Materials and Methods}

Study Area (Fig. 1): Fish and environmental variables were collected from eight streams covering the Alaknanda and Bhagirathi basins of the upper Ganga River. These basins are located in the hilly north-western part of Uttarakhand. The basins cover a total catchment area of $19,600 \mathrm{~km}^{2}$ up to Devprayag. Both basins are characterized by rugged river drainages, with deep, steep river valleys separated by linear narrow ridges. The slopes of these river valleys are quite unstable in certain regions. Many snow-fed streams originate from altitudes of 4016 to $3900 \mathrm{~m}$ in the Gharhwal Himalayas of Uttarakhand state (Asha et al.,
2012). Fish specimens and environmental data for this study were initially collected from four sites (Bhirai, Pindar, Bhagwan and Nayar; Fig. 1) in the Alaknanda river between May and June 2011. Fish specimens from an additional four sites (Kali, Madhmaheshwar, Asiganga and Bhilangana) as well as all environmental data were collected between May and June 2012 (Table 1). Sites were selected to maximize variation in different environmental variables. Schizothorax richardsonii is not known to occur above $1600 \mathrm{~m}$ mean sea level in these river basins (Asha et al., 2012).

Table 1: Summary of general features of study streams in upper Ganga river basin, India.

\begin{tabular}{|c|c|c|c|c|c|c|c|}
\hline Stream Name & $\begin{array}{c}\text { Latitude/ } \\
\text { Longitude } \\
\text { coordinates }\end{array}$ & $\begin{array}{l}\text { Alt. } \\
\text { (m) }\end{array}$ & $\begin{array}{c}\text { Water } \\
\text { temp. } \\
\left({ }^{\circ} \mathrm{C}\right)\end{array}$ & $\begin{array}{c}\text { Flow } \\
(\mathrm{m} / \mathrm{Sec})\end{array}$ & $\begin{array}{c}\text { Depth } \\
(\mathrm{cm})\end{array}$ & $\begin{array}{c}\text { Conduct } \\
\text { ivity } \\
(\mathrm{mS} / \mathrm{m})\end{array}$ & $\begin{array}{c}\text { Substrate } \\
\text { types } \\
(\%)\end{array}$ \\
\hline Kali & $\begin{array}{l}30.3329 \mathrm{~N} \\
79.0458 \mathrm{E}\end{array}$ & 1245 & $\begin{array}{c}14.5 \\
\pm 0.07\end{array}$ & $\begin{array}{c}0.68 \\
\pm 0.119\end{array}$ & $\begin{array}{c}45 \\
\pm 15.2\end{array}$ & $\begin{array}{c}0.025 \\
\pm 0.001\end{array}$ & $\begin{array}{l}\text { bedrock, } 65 ; \\
\text { boulders, } 25 ; \\
\text { cobbles, } 5 ; \\
\text { gravels, } 5 \text {. }\end{array}$ \\
\hline Madhmaheshwar & $\begin{array}{l}30.3232 \mathrm{~N} \\
79.0618 \mathrm{E}\end{array}$ & 1140 & $\begin{array}{c}15.2 \\
\pm 0.07\end{array}$ & $\begin{array}{c}0.53 \\
\pm 0.173\end{array}$ & $\begin{array}{c}52 \\
\pm 13.2\end{array}$ & $\begin{array}{c}0.022 \\
\pm 0.001\end{array}$ & $\begin{array}{l}\text { bedrock, 60; } \\
\text { boulders, 20; } \\
\text { cobbles, 10; } \\
\text { gravels, 5; } \\
\text { sand, } 5 .\end{array}$ \\
\hline Bhirai & $\begin{array}{l}30.2411 \mathrm{~N} \\
79.2247 \mathrm{E}\end{array}$ & 1030 & $\begin{array}{c}16.5 \\
\pm 0.07\end{array}$ & $\begin{array}{c}0.25 \\
\pm 0.069\end{array}$ & $\begin{array}{l}34.5 \\
\pm 14\end{array}$ & $\begin{array}{c}0.036 \\
\pm 0.001\end{array}$ & $\begin{array}{l}\text { bedrock, } 40 ; \\
\text { boulders, } 30 ; \\
\text { cobbles, } 10 ; \\
\text { gravels, } 10 ; \\
\text { sand, } 10 .\end{array}$ \\
\hline Bhilangana & $\begin{array}{l}30.2842 \mathrm{~N} \\
78.4223 \mathrm{E}\end{array}$ & 1151 & $\begin{array}{c}18 \\
\pm 0.07\end{array}$ & $\begin{array}{l}0.185 \\
\pm 0.05\end{array}$ & $\begin{array}{c}68 \\
\pm 10\end{array}$ & $\begin{array}{c}0.17 \\
\pm 0.006\end{array}$ & $\begin{array}{l}\text { bedrock, } 50 ; \\
\text { boulders, } 30 \\
\text { cobbles, } 10 ; \\
\text { sand, } 10 .\end{array}$ \\
\hline Asiganga & $\begin{array}{l}30.4551 \mathrm{~N} \\
78.2806 \mathrm{E}\end{array}$ & 1262 & $\begin{array}{c}16.8 \\
\pm 0.06\end{array}$ & $\begin{array}{l}0.46 \\
\pm 0.1\end{array}$ & $\begin{array}{l}56.5 \\
\pm 11\end{array}$ & $\begin{array}{c}0.125 \\
\pm 0.001\end{array}$ & $\begin{array}{l}\text { bedrock, } 60 ; \\
\text { boulders, } 20 \text {; } \\
\text { sand, } 20 .\end{array}$ \\
\hline Pindar & $\begin{array}{l}30.1321 \mathrm{~N} \\
79.1517 \mathrm{E}\end{array}$ & 811 & $\begin{array}{c}18.5 \\
\pm 0.06\end{array}$ & $\begin{array}{c}0.16 \\
\pm 0.06\end{array}$ & $\begin{array}{c}75 \\
\pm 16\end{array}$ & $\begin{array}{c}0.16 \\
\pm 0.003\end{array}$ & $\begin{array}{l}\text { bedrock, } 20 ; \\
\text { boulders, } 25 ; \\
\text { cobbles, } 15 ; \\
\text { gravels, } 10 ; \\
\text { sand, } 25 ; \\
\text { leaf litter, } 5 \text {. }\end{array}$ \\
\hline Bhagwan & $\begin{array}{l}30.0180 \mathrm{~N} \\
78.3525 \mathrm{E}\end{array}$ & 780 & $\begin{array}{c}21 \\
\pm 0.33\end{array}$ & $\begin{array}{l}0.135 \\
\pm 0.02\end{array}$ & $\begin{array}{c}42 \\
\pm 15\end{array}$ & $\begin{array}{c}0.22 \\
\pm 0.008\end{array}$ & $\begin{array}{l}\text { bedrock, } 10 ; \\
\text { boulders, } 25 ; \\
\text { cobbles, } 30 ; \\
\text { gravels, } 15 ; \\
\text { sand, } 20 .\end{array}$ \\
\hline Nayar & $\begin{array}{l}29.5959 \mathrm{~N} \\
78.4841 \mathrm{E}\end{array}$ & 701 & $\begin{array}{c}22.5 \\
\pm 0.07\end{array}$ & $\begin{array}{c}0.12 \\
\pm 0.03\end{array}$ & $\begin{array}{c}86 \\
\pm 14\end{array}$ & $\begin{array}{c}0.18 \\
\pm 0.001\end{array}$ & $\begin{array}{l}\text { bedrock, 5; } \\
\text { boulders, } 15 ; \\
\text { cobbles, } 25 ; \\
\text { gravels, } 20 ; \\
\text { sand, 25; } \\
\text { leaf litter, } 10 .\end{array}$ \\
\hline
\end{tabular}


Fish and Environmental data collection: The cyprinid Schizothorax richardsonii (snow trout) was selected for this study as it is the most abundant and widely distributed species in the streams/ rivers of the Himalayas (Talwar \& Jhingran, 1991). This species does not vary morphologically throughout life history stages, and is therefore an excellent candidate species to study the influence of environmental variables on morphology (Fig. 2). Fish were collected using monofilament gill nets and cast nets. Gill nets were set up across the stream width for one hour and cast nets were operated simultaneously along the habitat (Johnson \& Arunachalam, 2009). Fish were then fixed in buffered formalin (10\%) and the specimens were transferred to the laboratory for morphometric analysis. At each site, a $50 \mathrm{~m}$ long section of the stream was selected and $2 \mathrm{X}$ $2 \mathrm{~m}$ grids were used to record water depth, velocity, water temperature and conductivity at $2 \mathrm{~m}$ intervals. Water temperature (precision: \pm $0.1^{\circ} \mathrm{C}$ ) and conductivity (precision: $\pm 1 \%$ of reading $\pm 0.01 \mathrm{mS} / \mathrm{m}$ ) were recorded using a Hydrolab water quality monitoring system (Model: Quanta). Percentage composition of different substrate types (bedrock, boulders, cobbles, gravels sand or leaf litters) within each quadrat was visually scored. Depth was measured with a graduated $2 \mathrm{~m}$ steel rod (precision: $1 \mathrm{~cm}$ ) and water velocity was measured using a pigmy water flow meter with a velocity logger (propeller type: model no. 11250 , precision: $0.01 \mathrm{~m} / \mathrm{sec}$ ). We also recorded GPS co-ordinates and altitude at each site.

Ecomorphological studies: In the laboratory, we measured six ecomorphological attributes (three body morphological traits and three fin attributes): (1) Index of compression (IC) was calculated from a body depth measurement taken at the dorsal fin origin divided by the maximum body width along the lateral side just below the dorsal fin origin (Gatz, 1979); (2) Relative body depth (RBD) was defined as the body depth measurement near the dorsal fin divided by fish standard length (Gatz, 1979); (3) Index of trunk shape (ITS) was measured as the perpendicular distance from the tip of the snout to the horizontal point of maximum body depth divided by the standard length (Gatz, 1979); (4) Relative surface area of the pectoral fin (RAPF): was calculated as the pectoral fin area divided by fish total body area. Relative pectoral fin surface area was measured as the ratio of the areas of these drawings (Gatz, 1979); (5) Relative surface area of the dorsal fin (RADF) was measured as the dorsal fin area divided by the body area (Gosline, 1971); (6) Pectoral fin aspect ratio (PFAR) was calculated as the maximum length of the pectoral fin (leading edge) divided by its maximum width (Gatz, 1979). Leading edge is the distance from the base of the pectoral fin to the extreme tip of the fin at its longest point (Binning \& Fulton, 2011, Gatz, 1979; Wainwright et al., 2002). The pectoral and dorsal fins were removed from the fish, placed fully extended on paper and their outlines traced. Similarly, the outlines of entire lateral side of fish body were traced on paper. Distances and areas were estimated from the tracings (Gatz, 1979; Mahon, 1984).

With the exception of substrate diversity, all environmental data were $\log _{10}$ transformed to improve normality and linearize the data. Percentage composition of different substrate categories at each site were converted into a substrate diversity index ( $\left.\mathrm{H}^{\prime} / \mathrm{Hmax}\right)$ as described by Pusey et al. (1993). All environmental data were used in a principal component analysis (PCA) to generate composite environmental variables. PCA was also used to calculate two composite morphological variables: one composed of body size variables and the other composed of fin variables. Pearson's correlation was used to evaluate the relationship between composite body size and fin shape variables. Pearson's correlation was also used to evaluate the relationship between estimated means for each group of attributes from each population $(n=8)$ generated from morphological and environmental PCA variables following Binning et al. (2010). All statistical analyses were performed in SPSS (ver. 15).

\section{Results \\ Environmental variables}

Environmental variables differed across sites (Table 1). The high altitude streams, Kali and Madhmaheshwar, had relatively low water temperatures and conductivity and high water velocity. Low altitude streams, Nayar and Bhagwan, experience low water flow and slightly elevated temperatures and conductivity relative to the high altitude streams. PCA on environmental variables generated two axes with eigenvalues 3.64 and 0.77 respectively, which together explained $88.2 \%$ of the 
variance. PC1 was strongly related to water temperature (loading $=0.96$ ), conductivity (loading $=0.93$ ) and substrate heterogeneity (loading $=0.82$ ), whereas $\mathrm{PC} 2$ was only strongly related to depth (loading $=0.79$ ).

\section{Morphological data}

A total of 88 individuals of Schizothorax richardsonii collected from eight streams in the upper Ganga river basin were examined for body size and fin morphology (Table 2). Fish from the Nayar stream had a relatively high index of compression (mean 1.38) compared to other populations. As for the fin attributes measured, fish from the Kali stream had slightly higher relative dorsal and pectoral fin areas (mean 0.17 and 0.13 respectively), whereas the pectoral fin aspect ratio was higher for populations from Pindar and Nayar streams (mean 1.31 and 1.30 respectively). PCA on three body size measurements produced two principal components with eigenvalues 1.21 and 1.07 respectively that together explained $76.05 \%$ of the variance (Table 3). PC1 was strongly related to high index of compression (loading $=0.78$ ) and index of trunk shape (loading $=0.77$ ). PC2 was strongly related to relative body depth (loading $=0.92$ ). Similarly, two principal components were extracted from the three fin traits. PC1 had an eigenvalue of 1.7 explaining $56.95 \%$ of the variance, whereas PC2 had an eigenvalue of 0.91 explaining $30.36 \%$ of the variance. PC 1 was positively related to the relative dorsal fin area (loading $=$ 0.88 ) and relative area of the pectoral fin (loading $=0.85$ ), whereas PC 2 was positively related to pectoral fin aspect ratio (loading $=$ 0.889). Pearson correlation revealed a significant negative relationship $(r=-0.676 ; p$ $>0.01, \mathrm{n}=88$ fish) between the first PC body morphology and PC1 for fin traits (Fig. 3).

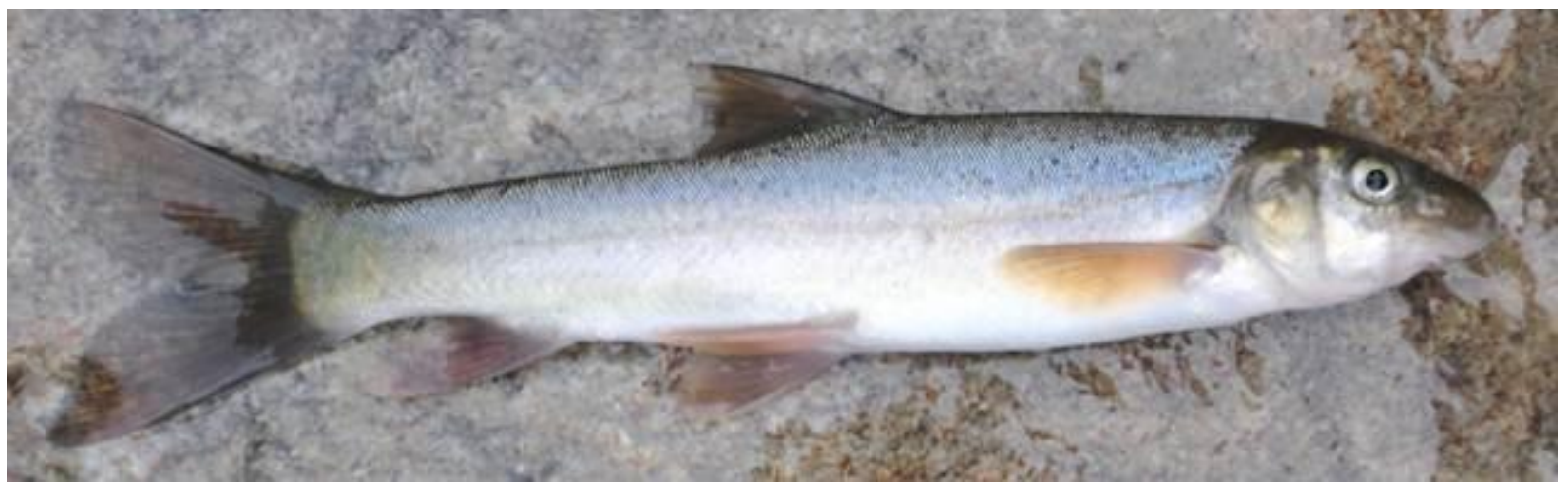

Figure 2: Lateral view of the Himalayan snow trout Schizothorax richardsonii

Table 2: Means $( \pm \mathrm{SD})$ of the body and fin measures calculated for Schizothorax richardsonii from eight different streams in the upper Ganga River basin, India (IC, index of compression; ITS, index of trunk shape; RBD, relative body depth; RDFA, relative surface area of the dorsal fin; RAPF, relative surface area of the pectoral fin; PFAR, pectoral fin aspect ratio).

\begin{tabular}{lcccccccc}
\hline Character & $\begin{array}{c}\text { Kali } \\
(n=12)\end{array}$ & $\begin{array}{c}\text { Madhmaheshwar } \\
(n=8)\end{array}$ & $\begin{array}{c}\text { Bhirai } \\
(n=8)\end{array}$ & $\begin{array}{c}\text { Bhilangana } \\
(n=10)\end{array}$ & $\begin{array}{c}\text { Asiganga } \\
(n=12)\end{array}$ & $\begin{array}{c}\text { Pindar } \\
(n=8)\end{array}$ & $\begin{array}{c}\text { Bhagwan } \\
(n=5)\end{array}$ & $\begin{array}{c}\text { Nayar } \\
(n=25)\end{array}$ \\
\hline IC & 1.25 & 1.25 & 1.23 & 1.24 & 1.32 & 1.23 & 1.27 & 1.38 \\
& \pm 0.05 & \pm 0.03 & \pm 0.02 & \pm 0.06 & \pm 0.06 & \pm 0.02 & \pm 0.04 & \pm 0.1 \\
ITS & 0.43 & 0.44 & 0.51 & 0.47 & 0.49 & 0.53 & 0.52 & 0.52 \\
& \pm 0.01 & \pm 0.01 & \pm 0.01 & \pm 0.03 & \pm 0.02 & \pm 0.03 & \pm 0.01 & \pm 0.02 \\
RBD & 0.22 & 0.23 & 0.21 & 0.26 & 0.25 & 0.21 & 0.23 & 0.22 \\
& \pm 0.01 & \pm 0.01 & \pm 0.01 & \pm 0.01 & \pm 0.01 & \pm 0.02 & \pm 0.02 & \pm 0.02 \\
RDFA & 0.17 & 0.15 & 0.12 & 0.15 & 0.14 & 0.13 & 0.15 & 0.13 \\
& \pm 0.02 & \pm 0.02 & \pm 0.02 & \pm 0.01 & \pm 0.01 & \pm 0.01 & \pm 0.01 & \pm 0.02 \\
RAPF & 0.13 & 0.11 & 0.10 & 0.10 & 0.09 & 0.10 & 0.10 & 0.08 \\
& \pm 0.01 & \pm 0.12 & \pm 0.01 & \pm 0.01 & \pm 0.01 & \pm 0.01 & \pm 0.00 & \pm 0.01 \\
PFAR & 1.26 & 0.12 & 1.20 & 1.28 & 1.24 & 1.31 & 1.25 & 1.30 \\
& \pm 0.09 & \pm 0.01 & \pm 0.08 & \pm 0.01 & \pm 0.09 & \pm 0.06 & \pm 0.06 & \pm 0.09 \\
\hline
\end{tabular}




\section{Morphology and environmental variables}

Pearson correlation analysis revealed a very strong positive relationship between environment PC1 (water temperature, substrate diversity and conductivity) and body $\mathrm{PC} 1$ (Dorsal and pectoral fin area; $r=0.861 ; \mathrm{p}=$ 0.002 ) and a significant negative relationship between environment $\mathrm{PC} 1$ and fin $\mathrm{PC} 1$ (pectoral fin aspect ratio; $r=-0.845 ; p=0.004$ ). There was no relationship observed between environment PC2 and either body or fin PC scores (Table 4).
Table 4: Pearson correlation coefficient between PCs of morphological variations and environmental variables.

\begin{tabular}{llcc}
\hline Environment & $\begin{array}{c}\text { Body \& fin } \\
\text { attributes }\end{array}$ & r & p \\
\hline \multirow{5}{*}{ Envir PC1 } & Body PC1 & $\mathbf{0 . 8 6 1}$ & $\mathbf{0 . 0 0 2}$ \\
& Body PC2 & -0.122 & 0.386 \\
& Fin PC1 & $\mathbf{- 0 . 8 4 5}$ & $\mathbf{0 . 0 0 4}$ \\
& Fin PC2 & 0.230 & 0.291 \\
\hline & Body PC1 & -0.229 & 0.292 \\
Envir PC2 & Body PC2 & 0.539 & 0.083 \\
& Fin PC1 & 0.106 & 0.4 \\
& Fin PC2 & 0.276 & 0.253 \\
\hline
\end{tabular}

Table 3: Principal component scores and component matrix for environmental, body and fin measurements (IC, index of compression; ITS, index of trunk shape; RBD, relative body depth; RDFA, relative surface area of the dorsal fin; RAPF, relative surface area of the pectoral fin; PFAR, pectoral fin aspect ratio).

\begin{tabular}{cccccccc} 
& Eigenvalues & $\begin{array}{c}\% \text { of } \\
\text { Variance }\end{array}$ & $\begin{array}{c}\text { Water } \\
\text { temp. }\end{array}$ & Conductivity & Flow & $\begin{array}{c}\text { Substrate } \\
\text { heterogeneity }\end{array}$ & Depth \\
\hline Envir PC1 & 3.64 & 72.83 & 0.96 & 0.93 & -0.91 & 0.81 & 0.59 \\
Envir PC2 & 0.77 & 15.43 & -0.09 & 0.03 & 0.13 & -0.34 & 0.79 \\
& & & IC & ITS & RBD & & \\
Body PC 1 & 1.21 & 40.25 & 0.78 & 0.77 & 0.02 & & \\
Body PC 1 & 1.07 & 35.80 & 0.33 & -0.33 & 0.92 & & \\
& & & RDFA & RAPF & PFAR & & \\
Fin PC1 & 1.70 & 56.95 & 0.88 & 0.85 & -0.45 & & \\
Fin PC2 & 0.91 & 30.36 & 0.15 & 0.30 & 0.88 & & \\
\hline
\end{tabular}

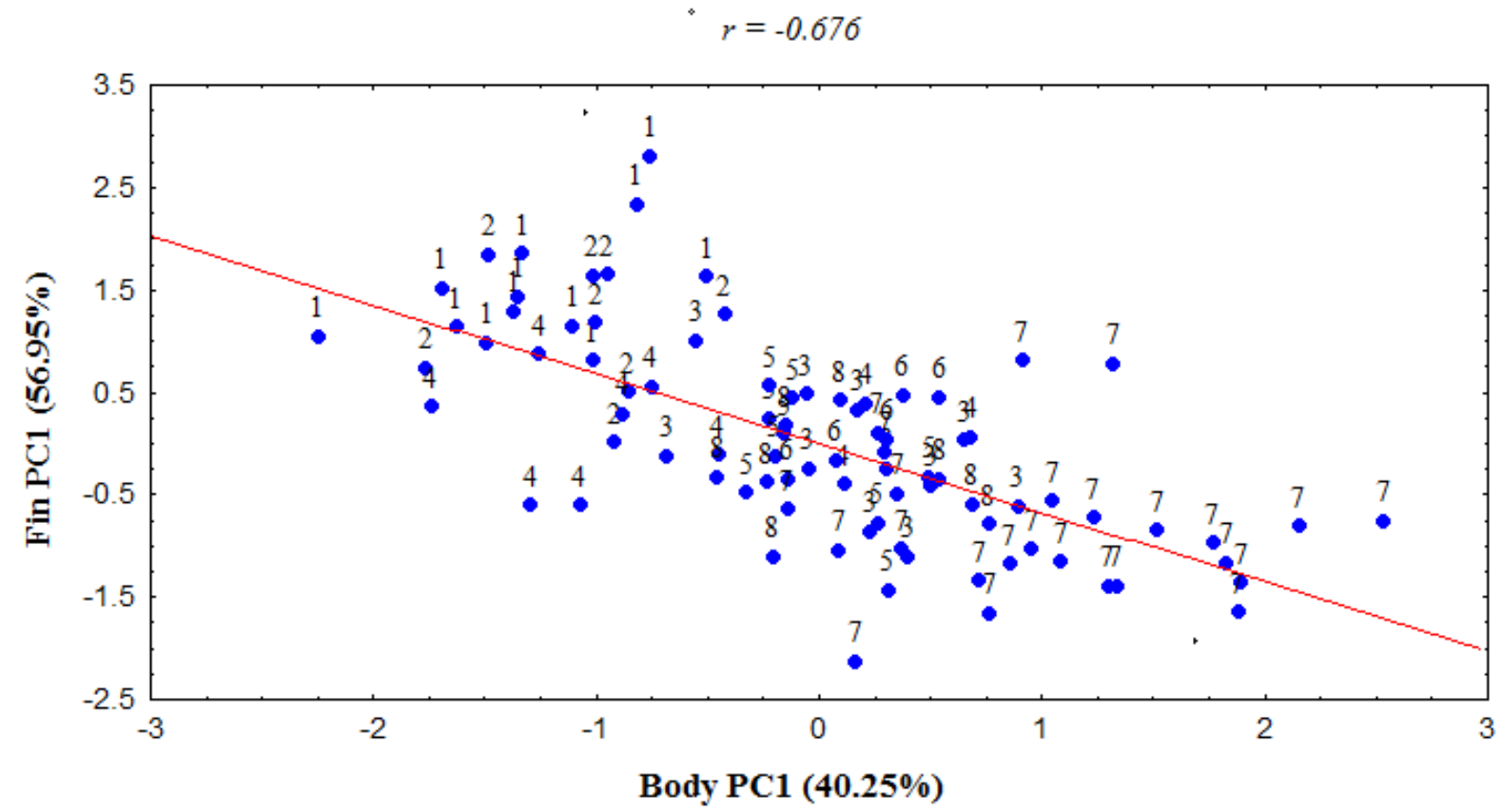

Figure 3: Relationship between the first principal component for body morphology and fin morphology across eight populations of Schizothorax richardsonii (1, Kali; 2, Madhmaheshwar; 3, Bhirai; 4, Bhilangana; 5, Asiganga; 6, Pindar; 7, Bhagwan; 8, Nayar). 


\section{Discussion}

Snow trout Schizothorax richardsonii are widely distributed spanning habitats across snow fed streams of the greater Himalayas to spring fed streams of the outer Himalayas. The present study documented distinct environmental gradients across eight distinct sites differing in a range of environmental variables. Water temperature, conductivity and habitat heterogeneity were most variable across sites. Streams of the Himalayas are typically characterised by swift flowing waters due to high altitudinal gradients, low dissolved ions and high diversity of substrate types (Brewin et al., 1995; Manel et al., 2000). The presence of Schizothorax richardsonii across a wide range of physico-chemical stream conditions suggests that it is a habitat generalist with a wide range of environmental tolerances.

Similarly, we found strong correlations between environmental and morphological variables suggesting that certain body and fin shapes may be adapted for a specific habitat. The first body principal component, which related strongly to the index of compression and index of trunk shape, was strongly correlated with environment PC1, which related to temperature, conductivity and habitat heterogeneity. Similarly, environment PC1 was also correlated with fin $\mathrm{PC} 1$, which was explained mostly by dorsal and pectoral fin area. These results suggest that and individual's body and fin morphology is influenced by the environmental conditions where they live, although more studies are needed to determine whether morphology is plastic in this species. Other studies have found similar relationships among body shape, fin size and various habitat features (Aleev, 1969; Dougles \& Mathews, 1992; Gatz, 1979). The negative correlation between body size and fin morphology suggests that increases in traits such as body width may lead to decreases in fin traits. Morphological trade-offs between sometimes unrelated structures have been well documented in other systems (Barel et al., 1989; Bellwood \& Wainwright, 2001; Binning et al., 2010; Chapman et al., 2008; Hoey et al., 2012; Norton et al., 1995). In this system, a more cylindrical body shape paired with small pectoral fins may enable individuals to better negotiate swift flowing habitats with high substrate heterogeneity (Chuang et al., 2006). Furthermore, the strong correlation between environmental PC1 and both body $(p=0.002)$ and fin morphology $(\mathrm{p}=0.004)$ suggests that environmental parameters such as water temperature, conductivity and substrate heterogeneity influence morphological trait differences observed across sites. Similar changes in the body morphology of Asian cyprinids were observed in individuals inhabiting high gradient, cold water (below $17^{\circ} \mathrm{C}$ ) streams (Chuang et al., 2006). Other studies show that water conductivity is an important factor for promoting good fish body condition in streams (Dennis et al., 1995; DiCenzo et al., 1995). Our results support the hypothesis that morphological traits of fish populations residing across environmental gradients tend to develop specific adaptations to their habitat as has been previously reported (Chan, 2001; Langerhans et al., 2003; Motta et al., 1995; Wood \& Bain, 1995). Moreover, fish body shape and fin size are two important morphological traits in this respect (Douglas \& Matthews, 1992; Gatz 1979).

\section{Acknowledgements}

We are indebted to the Director and Dean of the Wildlife Institute of India (WII) for their support and encouragement. We are also thankful to P. Gangaiamaran for his help during field sampling. Critical comments from an anonymous reviewer improved the quality of this manuscript and are sincerely appreciated.

\section{Literature Cited}

Aleev, Y. G., 1969. Function and gross morphology in fish. Israel Program for Scientific Translations (Translation from Russian). Keter Press, Jerusalem: 269.

Asha, R., A. Arora, V. B. Mathur, K. Sivakumar, S. Sathyakumar, G. S. Rawat, J. A. Johnson, K. Ramesh, N. K. Dimri and A. Maletha, 2012. Assessment of Cumulative Impacts of Hydroelectric Projects on Aquatic and Terrestrial Biodiversity in Alaknanda and Bhagirathi Basins, Uttarakhand. Wildlife Institute of India, Technical Report: 203.

Balon, E. K., S. S. Crawford and A. Lelek, 1986. Fish communities of the upper Danube River (Germany, Austria) prior to the new Rhein-MainDonau connection. Environmental Biology of Fishes, 154: 242-271.

Barel, C. D. N., G. C. Anker, F. Witte, R. J. C. Hoogerhoud and T. Goldschmidt, 1989. 
$\begin{array}{lcr}\text { Constructional anstraint and } & \text { its } \\ \text { ecomorphological } & \text { implications. } & \text { Acta }\end{array}$ morphologica Neerlando-Scandinavica, 27: 83109.

Bellwood, D. R. and P. C. Wainwright, 2001. Locomotion in labrid fishes: implications for habitat use and cross-shelf biogeography on the Great Barrier Reef. Coral Reefs, 20: 139-150.

Binning, S. A. and C. J. Fulton, 2011. Non-lethal measurement of pectoral fin aspect ratio in coral reef fishes. Journal of Fish Biology, 79: 812-818.

Binning, S. A., L. J. Chapman and J. Dumont, 2010. Feeding and breathing: trait correlations in an African cichlid fish. Journal of Zoology, 282 (2):140-149.

Bourke, P., P. Magnan and M. A Rodríguez, 1997. Individual variations in habitat use and morphology in brook charr. Journal of fish biology, 51: 783-794.

Brewin, P. A., T. M. L. Newman and S. J. Ormerod, 1995. Patterns of macroinvertebrate distribution in relation to altitude, habitat structure and land use in streams of the Nepalese Himalaya. Archiv für Hydrobiologie, 135: 79100.

Chan, M. D., 2001. Fish ecomorphologypredicting habitat preferences of stream fishes from their body shape. $\mathrm{PhD}$ dissertation, Virginia Polytechnic Institute and State University, Blacksburg, VA: 252.

Chapman, L. J., J. Albert and F. Galis, 2008. Developmental plasticity, genetic differentiation and hypoxia-induced trade-offs in an African cichlid fish. Open Evolution Journal, 2: 75-88.

Chuang, L. C., Y. S. Lin and S. H. Liang, 2006. Ecomorphological Comparison and Habitat Preference of 2 Cyprinid Fishes, Varicorhinus barbatulus and Candidia barbatus, in Hapen Creek of Northern Taiwan. Zoological Studies, 45 (1): 114-123.

Dennis, T. E., S. E. MacAvoy, M. B. Steg and A. J. Bulger, 1995. The association of water chemistry variables and fish condition in streams of Shenandoah National Park (USA). Water Air Soil Pollution, 85: 365-370.

DiCenzo, V. J., M. J. Maceina and W. C. Reeves, 1995. Factors related to growth and condition of the Alabama subspecies of spotted bass in reservoirs. American Journal of Fisheries Management, 15: 794-798.

Douglas, M. E. and W. J. Matthews, 1992. Does morphology predict ecology? Hypothesis is testing with in a freshwater stream fish assemblage. Oikos, 65: 213-224.

Gatz, A. J., 1979. Ecological Morphology of Freshwater Stream Fishes. Tulane Studies in Zoology \& Botany, 21: 91-124.

Gorman, O. T. and J. R. Karr, 1978. Habitat structure and stream fish community. Ecology, 59: 507-515.

Gosline, W. A., 1971. Functional morphology and classification of teleostean fishes. Honolulu, University Press of Hawaii: 208.

Hoey, A. S., D. R. Bellwood and A. Barnett, 2012. To feed or to breed: morphological constraints of mouth brooding in coral reef cardinal fishes. Proceedings of the Royal Society B: Biological Sciences, 279: 2426-2432.

Hubbs, C. L., 1941. The relation of hydrological condition to speciation in fishes, Pp. 182-195, In: a symposium on hydrobiology. University of Wisconin Press, Madison.

Johnson, J. A. and M. Arunachalam, 2009. Diversity, distribution and assemblage structure of fishes in streams of southern Western Ghats, India. Journal of Threatenedtaxa, 1: 507-513.

Langerhans, R. B., C. A. Layman, A. K. Langerhans and T. J. Dewitt, 2003. Habitat association morphological divergence in two Neotropical fish species. Biological Journal of Linnaean Society, 80: 689-698.

Mahon, R., 1984. Divergent structure in fish taxocenes of north temperate stream. Canadian Journal of Fisheries \& Aquatic Sciences, 41: 330-350.

Manel, S., S. T. Buckton and S. J. Ormerod, 2000. Testing large-scale hypotheses using surveys: the effects of land use on the habitats, invertebrates and birds of Himalayan Rivers. Journal of Applied Ecology, 37 (5): 756-770.

Motta, P. J., K. B. Clifton, P. Hernandez and B. T. Eggold, 1995. Ecomorphological correlates in ten species of subtropical seagrass fishes- diet and 
microhabitat utilization. Environmental Biology of Fishes, 44: 37-60.

Norton, S. F., 1995. A functional approach to ecomorphological patterns of feeding in cottid fishes. Environmental Biology of Fishes, 44: 6178.

Pusey, B. J., A. H. Arthington and M. G. Read, 1993. Spatial and temporal variation in fish assemblage structure in the Mary River, southeastern Queensland: the influence of habitat structure. Environmental Biology of Fishes, 37: 355-380.

Ricklefs, R. E. and G. W. Cox, 1977. Morphological similarity and ecological overlap among passerine birds on St. Kitts, British West Indies. Oikos, 29: 60-66.

Talwar P. K. and A. G. Jhingran, 1991. Inland fishes of India and adjacent countries. Oxford and IBH publication, New Delhi: 1158.

Wainwright, P. C., D. R. Bellwood and M. W. Westneat, 2002. Ecomorphology of locomotion in labrid fishes. Environmental Biology of Fishes, 65: 47-62.

Watson, D. J. and E. K. Balon, 1984. Ecomorphological analysis of fish taxocenes in rainforest streams of northern Borneo. Journal of fish biology, 25: 371-384.

Wikramanayake, E. D., 1990. Ecomorphology and biogeography of a tropical stream fish assemblage: evolution of assemblage structure. Ecology, 71: 1756-1764.

Wood, B. M. and M. B. Bain, 1995. Morphology and microhabitat use in stream fish. Canadian Journal of Fisheries and Aquatic Sciences, 52: 1487-1498. 